\title{
Survey of the medically important insects carried by the international aircrafts to Tokyo International Airport ${ }^{1)}$
}

\author{
Kazuki OGATA*, Ikuo TANAKA*, Yasutada ITO* \\ and Satomi MORII** \\ * Department of Environmental Biology, Japan Environmental \\ Sanitation Center, Yotsuya-kamicho, Kawasaki \\ ** Tokyo Airport Quarantine Station, Haneda Airport, Tokyo
}

(Received: June 18, 1974)

\begin{abstract}
In order to clarify the actual situation of insects of medical importance carried into Japan by aircrafts, the survey was conducted by checking the inside of the international aircrafts just after arriving at Tokyo International Airport, during the period from July 1972 to August 1973.

Of 42 aircrafts surveyed, 10 species of the pest insects, excluding several unidentified species, were captured in 24 aircrafts. Musca domestica Linné and Culex fatigans Wiedemann were collected most abundantly, 59 and 24, respectively. Of 10 species identified, 5 species were exotic ones and the other 3 were either the exceptional or rare ones around Tokyo. It is worth to note that an engorged female of Aedes aegypti (Linné), an important vector of yellow fever, and Anopheles subpictus Grassi, a malaria vector, were caught.

It must be emphasized that important mosquito species were carried mainly by the flights via Bangkok, Hongkong or Manila, whilst the house flies were abundantly carried by Seoul and Khavarovsk lines. In order to know the possible place where the mosquitoes embarked on the aircrafts, a discussion was made considering the actual time schedules of the flights. As for the house flies the levels of the insecticide susceptibility between the captured insects and Japanese colonies were compared.
\end{abstract}

With vast increase and speedy movement in international travel and exchange of goods in trade, the chance of invasion of diseases and their vectors from one country to another is presumed to remarkably be increasing. There have been a number of reports regarding the insects carried by aircrafts (Whitfield, 1939; Laird, 1952). In Japan, several records have been made about

1) This survey was supported by a 1972 Grant for Scientific Research on Health and Welfare, Ministry of Health and Welfare.

* 緒方一喜, 田中生男, 伊藤靖忠: 日本環境衛生七 ンター環境生物部（川崎市四谷上町 198)

** 森井達美 : 東京空港検疫所（東京都大田区羽田空 港) rodents and their parasitic fleas principally by the quarantine workers (Ikeda and Abe, 1967; Ohtomo, 1968). Nevertheless there was no report about the other insects, excepting a single paper of the cockroaches taken from overseas vessels (Hitomi, 1957). Even the quarantine has made no investigation on the situation of pest insects carried by international air transport. Therefore, through a period from July 1972 to August 1973, we conducted surveys to examine inside of the international aircrafts just after arriving at Tokyo International Airport.

\section{Method ANd PRocedure}

1. Selection of aircrafts surveyed. On 
Table 1 International aircrafts surveyed for insect pest at Tokyo International Airport, 1972-1973

\begin{tabular}{|c|c|c|c|c|}
\hline No. & date & $\begin{array}{l}\text { Time } \\
\text { surveyed }\end{array}$ & Equipment & Origin \& Transit \\
\hline & 1972 & & & \\
\hline 1 & 27 July & $13: 40$ & $\mathrm{DC} 8$ & NYC ANC (Cargo) \\
\hline 2 & & $14: 20$ & DC 8 & in hanger \\
\hline 3 & & $15: 00$ & Antonov 12 & KHV (Cargo) \\
\hline 4 & 18 Aug. & $19: 50$ & DC 8 & MEX YVR \\
\hline 5 & & $21: 00$ & B 747 & NYC LON IST KHI DEL BKK HKG \\
\hline 6 & & $02: 00$ & B 747 & AMS ATH BEY DEL BKK MNL \\
\hline 7 & 28 Aug. & $14: 05$ & B 707 & CAI BOM BKK MNL \\
\hline 8 & 13 Sep. & $14: 10$ & B 747 & CAI BOM BKK HKG \\
\hline 9 & & $14: 15$ & B 747 & SAO RIO LIM LAX \\
\hline 10 & & $14: 05$ & D C 8 & MNL \\
\hline 11 & 26 Sep. & $16: 20$ & D C 8 & SEL \\
\hline 12 & 2 Oct. & $14: 40$ & B 707 & CAI BOM BKK MNL \\
\hline 13 & 18 Oct. & $13: 20$ & B 707 & SAO RIO LIM LAX \\
\hline 14 & & $13: 40$ & DC 8 & MNL \\
\hline 15 & & $13: 50$ & B 707 & CAI BMB BKK HKG \\
\hline 16 & $4 \mathrm{Dec}$ & $13: 30$ & B 707 & CAI BOM BKK MNL \\
\hline 17 & & $14: 17$ & SVC 10 & LON EBB SEZ CMB HKG \\
\hline 18 & & $16: 40$ & DC 8 & TPE \\
\hline & 1973 & & & \\
\hline 19 & $23 \mathrm{Feb}$ & $16: 00$ & B 707 & GUM OSK \\
\hline 20 & & $13: 40$ & D C 8 & SYD MNL HKG \\
\hline 21 & & $15: 10$ & B 707 & SAO RIO LIM LAX \\
\hline 22 & & $15: 30$ & B 707 & LON FRA DXB CCU HKG (Cargo) \\
\hline 23 & 31 May & $18: 50$ & B 707 & BKK HKG \\
\hline 24 & & $19: 55$ & B 727 & SGN HKG TPE OSK \\
\hline 25 & & $21: 00$ & DC 8 & GVA ZRH ATH BOM BKK MNL \\
\hline 26 & & $21: 20$ & DC 8 & BKK HKG TPE \\
\hline 27 & & $21: 35$ & B 707 & BRU ATH BOM BKK MNL \\
\hline 28 & & $21: 50$ & B 747 & NYC LON IST BEY DEL BKK HKG \\
\hline 29 & 25 June & $14: 00$ & V C 10 & JNB SEZ CMB HKG \\
\hline 30 & & $14: 10$ & B 707 & CAI BOM BKK MNL \\
\hline 31 & & $16: 10$ & DC 8 & SEL \\
\hline 32 & & $16: 50$ & DC 8 & TPE \\
\hline 33 & 9 Aug. & $20: 30$ & $\mathrm{DC} 8$ & TPE OSK (Cargo) \\
\hline 34 & & $20: 45$ & B 707 & BRU ATH ROM BKK MNL \\
\hline 35 & & $21: 15$ & D C 8 & BKK HKG TPE \\
\hline 36 & & $21: 40$ & $\mathrm{DC} 8$ & JKT SIN HKG \\
\hline 37 & & $22: 10$ & D C 8 & SEL (Cargo) \\
\hline 38 & & $22: 15$ & D C 8 & ROM THR BOM BKK HKG \\
\hline 39 & & $22: 30$ & B 707 & PAR ATH BEY KHI BKK MNL OSK \\
\hline 40 & & $22: 50$ & B 747 & FRA ATH DEL BKK HKG \\
\hline 41 & 10 Aug. & $06: 15$ & DC 8 & SFO SEA ANC (Cargo) \\
\hline 42 & & $06: 20$ & D C 8 & BKK HKG TPE (Cargo) \\
\hline
\end{tabular}


the selection of aircrafts surveyed, special attention was paid to the aircrafts coming through the Southeast Asia, South America and Africa, where the insect-borne diseases are endemic. Though the intention was to include both passenger and cargo aircrafts equally, it resulted in that the majority of the surveyed aircrafts were the passenger ones due to the arrival schedules.

2. Aircrafts surveyed. The aircrafts investigated belonged to 18 airlines such as Air France, Aerollot Soviet Air Lines, Air Siam, Alitalia Airlines, BOAC British Airways, Egyptair, Flying Tiger, Japan Airlines, Korean Air Lines, KLM Royal Dutch Airlines, Lufthansa German Airlines, Pan American World Airways, Philippines Air Lines, Sabena Belgian World Airlines, Swissair, Thai Airways International, Varig Blazilian Airlines and Air Vietnam. The equipments, ports of origin and transit, and dates of aircrafts surveyed are shown in Table 1. Forty-two aircrafts, including 7 cargoes were checked during the period from July 1972 to August 1973.

3. Search and capture of insects. Effort was made to enter the aircrafts as soon as possible after they arrived, and actually we entered the aircrafts as the passengers and the crews disembarked. Flying, crawling or resting insects were hunted using flash lights, nets, forceps and the other tools, all the places such as passenger cabins, baggage and cargo compartments, cockpits, toilets, gallies and the others.

\section{RESLLTS}

The species and number of insects captured during the survey are shown in Tables ? and 3 . Of 42 aircrafts surveyed, 10 species of the pest insects, excepting several unidentified species, were captured in 24 aircrafts. House flies, Musca domestica Linné, followed in abundance by the common mosquitoes, Culex fatigans Wiedemann, were collected most abundantly, 59 and 24, respectively.

Of 10 species identified, 5 were the exotic ones and 3 do not occur, or very rare in Tokyo and its vicinities, though they occur in the other areas of Japan. As the remaining unidentified species seem also to be exotic, all captured pests, excluding house flies and German cockroaches, are presumably aliens in Tokyo. It is worth to mention that an engorged female of Aedes aegypti

Table 2 Insect pests of medical importance captured in the international aircrafts at Tokyo International Airport, 1972-1973

\begin{tabular}{|c|c|c|c|c|c|}
\hline species & male & female & larva & $\begin{array}{c}\text { egg } \\
\text { capsule }\end{array}$ & total \\
\hline Musca domestica & 27 & 32 & & & 59 \\
\hline Culex fatigans** & 9 & 15 & & & 24 \\
\hline Culex gelidus* & 0 & 2 & & & 2 \\
\hline Culex pseudovishnui** & 0 & 1 & & & 1 \\
\hline Culex sitiens group* & 0 & 1 & & & 1 \\
\hline Culex spp.* & - & - & & & 3 \\
\hline Aedes aegypti* & 0 & 1 & & & 1 \\
\hline Mansonia uniformis*** & 0 & 1 & & & 1 \\
\hline Anopheles subpictus* & 0 & 1 & & & 1 \\
\hline Supella longipalpa* & 1 & 0 & 1 & 1 & 3 \\
\hline Blattella germanica & 0 & (3) & 1 & & 1 \\
\hline Blatta spp. ${ }^{*}$ & 0 & - & 3 & & 3 \\
\hline Unknown flies* & - & - & & & 2 \\
\hline total & & & & & 102 \\
\hline
\end{tabular}

* Species not occuring in Japan

** Species not occuring in Tokyo area

( ) Number of dead collected 
Table 3 Insect pests captured in the international aircrafts just after landing at Tokyo International Airport, 1972-1973

\begin{tabular}{|c|c|c|c|c|c|c|c|}
\hline No. & $\begin{array}{r}\text { Musc } \\
\text { do }\end{array}$ & nestica & Cule. & tigans & $\begin{array}{l}\text { Other } \\
\text { mosquitoes }\end{array}$ & Cockroaches & Other flies \\
\hline & male & female & male & female & & & \\
\hline 3 & 10 & 9 & & & & & \\
\hline 5 & & 2 & & & & & \\
\hline 6 & 1 & & 1 & & & & Sepsidae so. \\
\hline 7 & & & 2 & 2 & Ae. aegypti & S. longipalpa & male 1 \\
\hline 8 & & 1 & 1 & 6 & female 1 & $\begin{array}{l}\text { larva } 1 \\
\text { Blatta sp. }\end{array}$ & \\
\hline 9 & & 3 & 1 & & & larva 1 & \\
\hline 10 & & & & & & $\left(\begin{array}{l}\text { S. longipalpa } \\
\text { egg cap. } 1\end{array}\right.$ & unknown 1 \\
\hline 11 & 2 & 4 & & & & larva 1 & \\
\hline 12 & & & & & C. gelidus & S. longipalpa & \\
\hline 13 & 2 & & & & female 1 & & \\
\hline 14 & 1 & 1 & & & 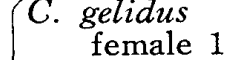 & & \\
\hline 15 & 1 & 1 & & 2 & $\begin{array}{l}\text { C. Pseudo- } \\
\text { vishnui } \\
\text { female } 1\end{array}$ & & \\
\hline 16 & & 3 & 2 & & C. sitiens & & \\
\hline 19 & & 1 & & & $\underset{\text { female } 1}{\text { group }}$ & & \\
\hline 22 & 1 & 1 & & 1 & Culex spp. 3 & & \\
\hline 23 & 2 & & & 3 & - An. subpictus & Blatta sp. & \\
\hline 24 & 3 & & & & $M \stackrel{\text { female } 1}{\text { uniformis }}$ & larva 1 & \\
\hline 25 & 1 & & & & female 1 & & \\
\hline 28 & 1 & & & & & & \\
\hline 30 & & 3 & 2 & 1 & & & \\
\hline 31 & 1 & 1 & & & & & \\
\hline 36 & 1 & & & & & & \\
\hline 38 & & 1 & & & & B. germanica & \\
\hline 39 & & 1 & & & & larva 1 & \\
\hline
\end{tabular}

No pest was obtained on the following eighteen flights ;

No. 1, 2, 4, 17, 18, 20, 21, 26, 27, 29, 32, 33, 34, 35, 37, 40, 41 and 42 .

Linné, an important vector of yellow fever, and Anopheles subpictus Grassi, a malaria vector, were caught.

Table 4 shows the results of the capture of insects according to the different original or final transit ports of the flights. Five hundred and twelve regular passenger flights arrived at Tokyo International Airport weekly in July 1973. Half of them belonged to the flights from Manila, Hongkong, Taipei and Bangkok (50.9\%), a quarter from Seoul and Moscow (21.0\%). Of 41 aircrafts surveyed (excluding No. 2 in the hanger), 24 $(58.4 \%)$ lodged the pests. As shown in Tables 1 and 3 , the considerable number of mosquitoes were found in the flights flown through either Cairo, Bombay, Bangkok, Hongkong or Manila. On the other hand, numerous flying house flies were captured in the cabins of the aircrafts from Seoul and Khabarovsk.

It seems rather difficult to decide the place where the mosquitoes entered the aircrafts. In order to reason that place to some degree, the actual time of the flights in which important vectors were collected are shown in Table 5. No. 7 flight, in which 4 fatigans and 1 aegypti were collected, landed in Manila and Cairo in the morning, and in Bombay and Bangkok at night. It seems very likely that $A e$. aegypti entered the stationary aircraft in Manila because of 
Table 4 Original or final transit ports of the passenger aircrafts surveyed at Tokyo International Airport, 1972-1973

\begin{tabular}{ll|c|c|c}
\multicolumn{1}{c|}{ Ports } & $\begin{array}{c}\text { No. of arrival } \\
\text { per week** }\end{array}$ & $\begin{array}{c}\text { No. of } \\
\text { surveyed } \\
\text { flights }\end{array}$ & $\begin{array}{c}\text { No. of flights } \\
\text { pests were found }\end{array}$ \\
\hline 1. MNL HKG TPE BKK & 261 & 23 & 13 \\
2. MOW SEL & 108 & 4 & 3 \\
3. ANC FAI SEA & 64 & 3 & 0 \\
4. HNL & 58 & 0 & - \\
5. Latin America* & 10 & 3 & 6 \\
6. Africa* & 8 & 8 & - \\
7. SYD & 3 & 0 & 24 \\
\hline
\end{tabular}

* indicates the original ports, the others show the final transit ports to Japan $* *$ in July, 1973

Table 5 The time schedule of the flights carried the important pests

\begin{tabular}{|c|c|c|c|c|c|c|c|}
\hline \multirow{2}{*}{ No. Flights } & \multicolumn{7}{|c|}{ Scheduled time (local time) } \\
\hline & & CAI & $\mathrm{BOM}$ & BKK & HKG & MNL & TKO \\
\hline \multirow{2}{*}{ No. 7} & arr. & & $19: 35$ & $02: 15$ & & $07: 50$ & $13: 35$ \\
\hline & dep. & $11: 45$ & $20: 50$ & $03: 00$ & & $08: 45$ & $(14: 35) *$ \\
\hline \multirow[t]{2}{*}{ No. 15} & arr. & & $19: 35$ & $02: 15$ & $09: 00$ & & $13: 25$ \\
\hline & dep. & $11: 45$ & $20: 50$ & $03: 00$ & $09: 45$ & & $(13: 40) *$ \\
\hline \multirow{2}{*}{ No. 23} & arr. & & & $14: 55$ & $12: 40$ & & $18: 10$ \\
\hline & dep. & & & $09: 00$ & $13: 30$ & & $(18: 45)^{*}$ \\
\hline
\end{tabular}

* actual arrival time due to deley

their diurnal flying activity. Whereas, in No. 15 and No. 23 flights, it is surmised that Culex, Anopheles and Mansonia mosquitoes invaded into the aircrafts in Bangkok or Bombay, due to their nocturnal activity. As another reason, Ae. aegypti, Culex gelidus Theobald, An. subpictus and Mansonia uniformis (Theobald) are known to be the commonest species at the environs of those airports, respectively.

\section{House flies}

The house flies were the most abundant pests found in the passenger cabins. In an instance, when the investigators entered the cargo aircraft, which just flown in from Khabarovsk, 20-30 house flies were found flying in the cargo compartment, which was empty, but scattered with vegetable wastes on the floor.

As it is morphologically impossible to distinguish them whether the flies captured are domestic or foreign. Therefore, the susceptibility tests of those flies against some insecticides were conducted. After colonization of the females collected in the aircrafts, the knockdown-time tests on the insecticide residues were conducted. Flies originated from two aircrafts, Antonov (No. 3) from Khabarovsk and B 747 (No. 5) from Hongkong through New York, London and Delhi, were tested. The susceptibiliy of $F 1, F 2$ and $F 3$ colonies to DDT and Diazinon residues, 50 $\mathrm{ml} / \mathrm{m}^{2}$ of $0.5 \%$ aceton solution on filter paper each, were evaluated with KT-50 values. The "Denken" strain, which is susceptible to organo-phosphorus compounds and highly resistant to organo-chlorine compounds, was exposed to the same residues, as the control for comparison.

As shown in Table 6, the insects brought from Antonov (No. 3) showed quicker knock- 
Table 6 Susceptibility tests of the house flies, captured in the international aircrafts, to insecticides

\begin{tabular}{l|ccc|c}
\multicolumn{1}{c|}{ Aircrafts } & $\begin{array}{c}\text { KT-50 values } \\
\text { (min.) } \\
\text { to diazinon }\end{array}$ & $\begin{array}{c}\text { Resistance } \\
\text { to DDT }\end{array}$ \\
\cline { 2 - 5 } & $\mathrm{F}_{1}$ & $\mathrm{~F}_{2}$ & $\mathrm{~F}_{3}$ & \\
\hline $\begin{array}{l}\text { Antonov (No. 3) } \\
\text { PAA (No. 5) }\end{array}$ & 13 & 12 & 16 & low \\
Denken strain & 25 & 17 & - & $\begin{array}{l}\text { high } \\
\text { high }\end{array}$ \\
\hline
\end{tabular}

down time on Diazinon residues and lower resistant level to DDT than those from B 747 (No. 5) and of the "Denken" strain. We conclude from the data that the flies from Antonov (No. 3) is most likely to be the intruder from U.S.S.R. However, we could not distinguish those from B 747 (No. 5) from the Japanese strain, since both the colonies showed a similar tendency of susceptibility to the insecticides. Nevertheless, considering scarcity of house flies in the apron of Tokyo International Airport and the capturing time just after the landing, it is also reasonable to consider those flies are the intruders.

\section{Mosquitoes}

Seven mosquito species, excepting unidentified species, were captured during the survey. Of them, C. fatigans was most common both in the cabins and the cargo compartments and it was distinguished clearly from Culex pipiens pallens Coquillett, which is common in Japan, by the morphological character of the male genitalia. It is noteworthy that $A e$. aegypti, An. subpictus and some other species, which do not occur in Japan, were found out. They were captured when flying and resting on the wall, and some of them were fully engorged. It must be emphasized that the majority of the aircrafts carried such important pest species were the flights from Bangkok, Hongkong or Manila.

\section{Cockroaches}

Two species, Supella longipalpa (Fabricius) and Blattella germanica (Linné), were collected, but the individual number collected was small. It was difficult, however, to catch alive cockroaches, due to their hiding habit in lighted condition. According to the witness of the land service personnels, the cockroach infestation is suspected to be heavier.

\section{DISCUSSION}

The insects of medical importance introduced to Japan from abroad on ships and aircrafts are controlled by quarantines under the International Health Regulations and National Quarantine Law. At Tokyo International Airport, according to the general declarations which are submitted to the quarantine by captains of aircrafts, most of them have been treated with insecticides about 30 minutes prior to departure or before landing. Nevertheless, unexpectedly abundant insect pests were found in the aircrafts just after landing on Tokyo International Airport. The insects captured by the investigators in the aircrafts, do not always mean insects which invade the country. But, on the other hand, it seems likely that many overlooked insects remain there, escaping the examinations.

Whitfield (1939) composed world wide records of insects taken in aircrafts, and investigated the insects collected from aircrafts at Khartum, to appraise the relation between air transport and the possible spread of malaria and yellow fever. He collected nearly 3,000 insects belonging to 146 species, after the examination of over 2,000 aircrafts. Laird (1952) collected 100 species of insects from 16 aircrafts which had arrived from the Pacific Islands. Of them, 26 species were of medical and economic importance. On the other hand, a number of experiments has been conducted to ascertain the ability of insects to survive long distance air travel, especially under condition of low temperature and reduced pressure (Whitfield, 1939 ; Sullivan et al., 1958). It may be concluded from the previous observations that insects are able to withstand long jurney if flight is under 12,000 feet or less. But, Sullivan et al. (1958) obtained high mortality of Ae. aegypti, $M$. domestica and B. germanica when exposed in unpressured and unheated sections 
of jet fighters and bombers. It is reported, at the height between 36,000 and 66,000 feet, the standard day temperature is $-69^{\circ} \mathrm{C}$, and the atmospheric pressure is one-fifth of that at sea level. According to the information of Japan Airlines, the most of passenger aircrafts surveyed were generally kept at atmospheric pressure of 0.775 -fold of that at sea level. Moreover, the cargo compartments as well as cabins were heated, and the temperature was kept between $5^{\circ} \mathrm{C}$ and $20^{\circ} \mathrm{C}$ in DC 8 and $\mathrm{B} 747$, according to the observation at one time. It may be considered that the insects are able to survive in the space conditioned as above.

Recently, Ohtomo et al. (1974) reported a case of malaria occured near Tokyo International Airport. They stated that the infection route remained obscure, because there has been no indigenous malaria in Japan since 1950, besides the patient has never been abroad, and so far she had never had opportunity of acquiring induced malaria. Thus, they presumed probably to be such an introduced case, as the parasite relapse after a long time incubation period, or as a new infection by imported infective mosquito vector. On this connection, it is very important fact that several vector mosquitoes such as $A n$. subpictus and Ae. aegypti were captured during the present survey.

At present time, the studies of aircraft disinfection at "blocks away" are being carried out by Sullivan et al. (1964) with the cooperation of WHO (1971). This measure is the disinfection by means of single-dose, disposal dispensers at "blocks away" which means treatment of the passenger cabin and all accessible interior space of aircraft, after the doors have been locked following embarkation and before actual take-off. Nevertheless, from our results, it is doubtful whether the disinfection operation is being actually carried out or not.

\section{ACKNOWLEDGEMENT}

We extend our appreciation to Dr. T. Aida. Director of Tokyo Airport Quarantine Station, for his kind consideration through the survey, to Dr. T. Kurihara, Dept. Parasitology, Teikyo University School of Medicine, for his identification of some mosquitoes, and to Mr. K. Mizutani,
Mr. A. Shimada and Miss M. Komiyama, Japan Environmental Sanitation Center, for their excellent technical assistance.

\section{REFERENCES}

Hitomi, M. (1957): Cockroaches prevalent in oversea vessels with special reference to Blattella germanica L. Jap. J. Sanit. Zool., 8(3): 112-118.

Ikeda, O. and H. Abe (1967): Studies on the rats and fleas in the harbor areas of Yokohama and Kawasaki. 1. On the harbor side areas. Jap. J. Sanit. Zool., $18(4): 279-283$.

Ikeda, O. (1967): Ibid 2. Rodents in the overseas ship. Jap. J. Sanit. Zool., 18(4) : 284-288; 3. Fleas in the overseas ships. Jap. J. Sanit. Zool., $18(4)$ : 288 290.

Laird, M. (1952) : Insects collected from aircrafts arriving in New Zealand during 1951. $J$. Ariation Med., $23(3)$ : 280-285.

Ohtomo, H., T. Koyama, T. Kobayakawa and H. Shionoiri (1974): A case of infection of vivax malaria in Japan. Japan. Med. J., $2579: 30$ 32.

Ohtomo, T. (1968): Rodents and their fleas in the harbor areas in Japan. $142 \mathrm{pp}$. Ministry of Health and Welfare.

Sullivan, W. N., F. R. Du Chanois and D. L. Hayden (1958): Insect survival in jet aircraft. J. Econ. Ent., $51(2): 239-241$.

Sullivan, W. N., J. C. Azurin, J. W. Wright and N. G. Gratz (1964) : Studies on aircraft disinfection at "blocks away" in tropical areas. Bull. Wld. Hlth. Org., 30 : 113-118.

Warren, F. P., S. Thompson and R. Wilson 1968): The interception of living larvae of Aedes aegypti (L.) and Culex cinerellus $\mathrm{Edw}$. in aircraft. Mosq. News, $28(4): 646$.

Whitfield, F. G. S. (1939): Air transport, insects and disease. Bull. Ent. Res., $30(3): 365-$ 442.

WHO (1971): International Health Regulations 1969, Annex 6. 82 pp. WHO, Geneva.

\section{摘要}

\section{東京国際空港における国際線による} 侵入㕩虫の調查

東京国際空港に着陸する国際線航空機に，着陸後直ち に乗り远み，衛生害虫を探し，侵入菁虫の実態を調査し た. 1972 年 7 月から 1973 年 8 月にかけ 42 機を調へたた。 4 機を除きすべて旅客機であった。そのうち24機にお いて 10 種が採集されたが，この他に末同定のもの数種 があり，全部で個体数は 102 匹にのぼった。そのうち， 59 匹はイエバエ，24匹は六ッタイイエカで約 $83 \%$ を占 
めた． 10 種のうち，5種は日本に産しないもので，き らに 3 種は東京付近には稀のものであった. マラリアの ベクターAnopheles subpictus, 黄熱のベクターAedes aegypti が採れたことは注目されてよい.

蚊は, カイロ一バンコック一ホンコン・マニラ経由の 南まわり便に多く，イエバエは，ソウル，ハバロフスク からの飛来便に多い傾向がみられた，そして，これらの
蚊が，ぞこで航空機内に侵入したかを，フライト・スケ ジュールをもとに推理した. イエバエについては, 国内 産と外国産を形態的に区別できないので，殺虫剂感受性 を調心゙て，侵入したものかどうかを検討した．その結 果，ハバロフスクからの飛来便で採集したものは，明ら かに日本のものとは違った感受性傾向を示した。 